\title{
The Readiness of Future Specialists of Preschool Education to Creative Self-Realization in Professional Activity
}

\section{La preparación de los futuros especialistas de educación preescolar para la autorrealización creativa en la actividad profesional}

\author{
Nadia Ivanivna Lutsan* \\ Vasyl Stefanyk Precarpathian National University, Ukraine. \\ ORCID: https://orcid.org/0000-0001-6239-1535 \\ Anna Vasylivna Struk \\ Vasyl Stefanyk Precarpathian National University, Ukraine. \\ ORCID: https://orcid.org/0000-0001-6442-8098 \\ Vitalina Viacheslavivna Liubyva \\ Oleksandr Dovzhenko Hlukhiv National Pedagogical University, Ukraine \\ ORCID: https://orcid.org/0000-0003-2228-2013 \\ Inna Dmytrivna Kulish \\ Oleksandr Dovzhenko Hlukhiv National Pedagogical University, Ukraine \\ ORCID: https://orcid.org/0000-0002-2066-3923 \\ Valentyna Nikolaevna Vertuhina \\ Borys Grinchenko University Kyiv, Ukraine \\ ORCID: https://orcid.org/0000-0002-8294-9193
}

Recibido 12-12-19 Revisado 13-02-20 Aprobado 30-04-20 En línea 04-05-20

Correspondencia

Email: nlutsan@bk.ru
Citar como:

Ivanivna, N., Vasylivna, A., Viacheslavivn, V., Dmytrivna, I., \& Nikolaevna, V. (2020). The Readiness of Future Specialists of Preschool Education to Creative Self-Realization in Professional Activity. Propósitos y Representaciones, 8(3). doi: http://dx.doi.org/10.20511/pyr2020.v8n3.531 


\section{Summary}

The article is devoted to the issue of future specialists of preschool education training to creative self-realization in professional activity. The authors of the article reveal the pedagogical diagnostics of readiness to creative self-realization in professional activity of higher educational institutions' students. The purpose of the study is to reveal the results of pedagogical diagnostics of future specialists of preschool education readiness to creative self-realization in professional activity. A diagnostic methodology and criteria of future specialists of preschool education to creative self-realization in professional activity readiness has developed. The criteria of future specialists of preschool education to creative self-realization in professional activity readiness are: motivational and valuable, creative activity, assessment and reflective. Each criterion includes a group of quality indicators. The methodological tools was developed, which was used for pedagogical diagnostics of this professional quality forming in future specialists of preschool education. The experimental study helped to identify the characteristics of qualitative measurements for primary, reproductive and creative levels of readiness of future preschool teachers' professional training. We see the prospect of further research in the development of methodology of future specialists of preschool education preparing to creative self-realization in professional activity.

Keywords: Readiness; Preschool Education; Creative Self-realization; Professional Activity.

\section{Resumen}

El artículo está dedicado a la cuestión de los futuros especialistas de formación en educación preescolar para la autorrealización creativa en la actividad profesional. Los autores del artículo revelan el diagnóstico pedagógico de la preparación para la autorrealización creativa en la actividad profesional de los estudiantes de instituciones de educación superior. El propósito del estudio es revelar los resultados del diagnóstico pedagógico de futuros especialistas en preparación para la educación preescolar para la autorrealización creativa en la actividad profesional. Se ha desarrollado una metodología diagnóstica y criterios de futuros especialistas de educación preescolar para la autorrealización creativa en la preparación para la actividad profesional. Los criterios de los futuros especialistas de la educación preescolar para la autorrealización creativa en la preparación para la actividad profesional son: motivadores y valiosos, actividad creativa, evaluación y reflexión. Cada criterio incluye un grupo de indicadores de calidad. Se desarrollaron las herramientas metodológicas, que se utilizaron para el diagnóstico pedagógico de esta calidad profesional formando en futuros especialistas de educación preescolar. El estudio experimental ayudó a identificar las características de las mediciones cualitativas para los niveles de preparación primaria, reproductiva y creativa de la formación profesional de los futuros maestros de preescolar. Vemos la posibilidad de una mayor investigación en el desarrollo de la metodología de futuros especialistas en educación preescolar que se preparan para la autorrealización creativa en la actividad profesional.

Palabras clave: Preparación; Educación preescolar; Autorrealización creativa; Actividad profesional.

\section{Introduction}

Modern socio-economic, political, and cultural transformations actualize the issue of education modernizing and new educational paradigms searching that are focused on the development of creative personality. 
The introduction of a personal-oriented learning model into the modern practice of educational institutions requires students to have a creative attitude to their future professional activity.

The relationship between the process of future specialists of preschool education institutions personality formation and the effectiveness of their professional functions is evidenced by the results of numerous theoretical studies of Ukrainian and foreign scientists. The issue of the individual professional development is presented in a number of fundamental methodological, general theoretical and empirical studies.

The scientists focus on personal development and professionalization of the teacher (H. Ball (1994), N. Kuzmina (1990), V. Kan-Kalyk (1990) and other); on the importance of such components as professional knowledge, professional self-determination, professional consciousness and self-awareness in teacher training (O. Dubaseniuk (2017), N. Zhyhailo (2019), S. Maksymenko (1994), V. Semychenko (2004), N. Chepielieva (2016) and other).

Deserves attention the scientific researches, concerning the professional training of teachers and their readiness to professional activity of such scientists as H. Bielienka (2011), L. Biriuk (2018), A. Bohush (2017), K. Durai-Novakova (1983), M. Diachenko, L. Kandybovych (1998), N. Lutsan (2019) and other.

Of particular importance for our research are the works of scientists, which reflect the process of future preschool specialists' training and its results. They are readiness or professional competence. For example, professional training of future preschool teachers for preschoolers' physical education was investigated by Yu. Kovalenko (2006), S. Petrenko (2005), O. Shovkoplias (2012) and other.

Work in families was investigated by A. Zalizniak (2009), N. Kovalevska (2007) and other. Using the computer technologies in work with children was investigated by I. Mardarova (2012); the prognostic activity was investigated by N. Davkush (2012); creative professional activity in work with children was investigated by N. Holota (2000), O. Lystopad (2015), L. Makridina (1996) and other; teaching a foreign language to preschoolers was investigated by I. Mordous (2011), T. Shkvarina (2003); ecological education of preschoolers was investigated by T. Naumenko (2008) and other.

Self-realization is one from the important components of future specialists' quality education ensuring. In the same time the future specialists are the translators of universal values for preschoolers and it actualizes the improvement of their professional and pedagogical training.

In pedagogical science, the issue of personal self-realization is considered in the context of professional self-improvement, self-education, self-determination, and self-education. It is defined as one of the goals of the pedagogical process.

The problem of self-realization in a professional context is tangent to the research topic. Choosing a profession, a person chooses a way of life and lifestyle. The choice of profession determines the place of residence, the level of material wealth and the degree of freedom for creativity and the level of satisfaction with life in general depends on the success of a professional career.

The issue of individual self-realization in the modern psychological and pedagogical science was researched by such scientists as I. Bekh (2003), S. Maksymenko (1994), V. Radul (2011), V. Slastionin (1981) and other. 
Some aspects of future teachers' self-realization in the process of their professional training are considered in the works of V. Demydenko (2004), L. Korostyliova (1996), N. Kuzmina (1990), A. Maslow (1954) and other.

Despite the numerous scientific studies of creative self-realization of pedagogues, the researchers are focused on the issues of creative self-realization of schoolteachers. The issue of future specialists of preschool education creative self-realization has not been thoroughly studied, and therefore is relevant and timely.

Considering the various approaches to the content of concepts «professional selfrealization» and «creative self-realization» definitions we can specify that the professional potential of the pedagogue is simultaneously as a characteristic of personal integrity and the level of social activity that has manifested in the pedagogical skills, creativity, professional and pedagogical culture.

Self-realization of the pedagogue occurs in the process of professional and pedagogical activity, which involves his direct interaction with other participants in the educational process and requires the disclosure of internal potential, the formation of stable personality qualities, an active position and a creative approach to solving the pedagogical tasks.

We understand the concept of «creative self-realization of future specialists of preschool education in professional activity» as a purposeful process of creative solution of professional tasks by a specialist (pedagogue), which has a pronounced individual and personal character (Liubyva, 2018).

The phenomenon of «readiness» was studied by such scientists as A. Kapska (1997), N. Kovalevska (2007), K. Durai-Novakova (1983) and other.

In particular, psychological readiness was investigated by D. Voitiuk (2004), V. Moliako (1995); motivational readiness was investigated by E. Tomas (2019); moral and psychological readiness was investigated by L. Kondrashova (1987); professional and pedagogical readiness was investigated by L. Biriuk (2018).

To understand the content of the concept «readiness», the researches of Ukrainian and foreign scientists about consciousness, self-consciousness and self-knowledge of a person are very important.

Readiness is an important condition for the success of any activity. A state of high readiness can be created through creative work with a high degree of novelty, and low readiness can be caused by a strong unmanageable emotionality of the person and manifest in distraction, lack of attention, false actions (Levitov, 1964).

S. Bryzgalova notes that the core of the phenomenon of readiness is psychological and practical readiness: psychological is the base and stable platform for activity and practical or professional readiness is the readiness to apply knowledge and skills (Bryzgalova, 2004).

O. Leontiev defines readiness as a short-term state that occurs under certain conditions on the basis of acquired experience, concerns only one of the stages of activity, and not the activity as a whole, since it consists of individual actions (Leontiev, 1983).

In the intersectoral scientific space, the phenomenon of concept «readiness to perform activities» is relevant. In general interpretation the concept «readiness to a certain type of activity» 
is defined by Ukrainain researchers (Maksymenko, 1994) as a purposeful expression of a person, containing person's beliefs, views, attitudes, motives, feelings, volitional and intellectual qualities, knowledge, skills, and instructions.

Based on the analysis of the scientific literature, it can be stated that there are two approaches to determining the content of the concept of «readiness for activity». They are: functional and personal. Functional approache considers «readiness» as a certain psychological state, an attitude that functions on the general activity of the individual (Levitov, 1964; Uznadze, 2001), and personal approach considers «readiness» as a system of integrative qualities, properties, knowledge, skills of the individual (Diachenko, Kandybovych, 1998; Voitiuk, 2004; Moliako, 1995).

The diversity in the interpretation of a person's readiness for a certain activity indicates that the forming of readiness is a complex and long process, and therefore it must be researched in stages. But, despite the divergence of opinions, almost all scientists determine that readiness is a complete system with its own structure. In the psychological and pedagogical literature, such integrity is presented as a set of qualities, properties and states of a person that help person to perform the professional activities.

H. Timofieieva (2006) investigated the issue of preschoolers' readiness forming to creativity. Analyzing the characteristics of preschool teachers' readiness forming to a creative activity the scientist links the genesis of concept «preschool teacher's readiness to a creative activity» with the development and enrichment of the concept of «psychological readiness to work» in the preschool educational institution, which is defined as a persistent mental condition, stemming from the need for labor. The researcher defines the readiness of preschool teachers for creative activity as «the ability to creative pedagogical activity focused on professional creativity and combines the need and ability of the preschool teacher to realize their strengths and capabilities in the interests of educating the creative personality of preschoolers and personal selfrealization».

A significant interest for the study of the issue of future preschool teachers' readiness forming for creative self-realization is represented by scientific researches of A. Bohush (2017), N. Lutsan (2019), V. Liubyva (2018) and others.

We understand the readiness of future preschool teachers to creative self-realization in professional activity as a multi-component individual-personal dynamic characteristic of the individual, represented by a stable internal motivation for creative activity and systematic creative self-development in the profession, thorough knowledge of pedagogical creativity, developed creative abilities, skills and abilities of creative activity.

The criteria of readiness to creative self-realization of future specialists of preschool education are the formation of the value-motivational sphere (motivational component), possession of theoretical knowledge, methods, technologies of child development (cognitive component), the ability to apply them in practice (activity component) (Liubyva, 2018).

The purpose of the article is to reveal the results of pedagogical diagnostics of future specialist of preschool education readiness to creative self-realization in professional activity.

Research objectives: 1) to develop criteria and indicators of readiness of the future specialist of preschool education to creative self-realization in professional activity. 2) to develop methodological tools for criteria and indicators and conduct pedagogical diagnostics to differentiate its levels in future specialists of preschool education. 


\section{Method of research}

The experimental study included 217 students: 105 in the experimental group (EG) and 112 in the control group (KG). The experimental study was conducted on the basis of Borys Grinchenko Kyiv University, Vasyl Stefanyk Precarpathian National University and Oleksandr Dovzhenko Hlukhiv National Pedagogical University.

Readiness to creative self-realization of future preschool education specialists was diagnosed by experimental methods, selected for each component of the readiness. For the level of future specialist of preschool education readiness to creative self-realization in professional activity was identified a number of criteria and indicators: motivational and valuable (indicators: positive attitude toward creative self-realization; interest in the chosen field of study; awareness of the need to creative self-realization by future teachers of preschool education); creative activity, (indicators: ability of future preschool teacher to solve pedagogical situations of various kinds of professional activity creatively; the ability to make long-term plans of individual creative selfrealization in professional activity; ability to determine the direction of preschoolers' creative development); assessment and reflective (indicators: capacity for self-assessment of readiness to creative self-realization in professional activity).

The outlined criteria were the basis for the development of appropriate methodological tools. Psychological and pedagogical diagnostics of future specialist of preschool education readiness to self-realization was hold with the students of «Preschool Education» specialty, which passed teaching practice in the preschool educational institutions.

According to the indicators of these criteria, a number of diagnostic tasks and questionnaires were developed. The using of certain criteria in the diagnosis process helped us to identify the state of future preschool education specialists to creative self-realization in professional activity readiness forming and on this basis to apply methods and forms of the most effective educational work in order to influence the process of readiness of future preschool education specialists to creative self-realization forming in professional activity.

During the diagnostics, methods and questionnaires were selected. To each of the specific criteria and indicators were selected the tasks, including: the formulation of concepts associated with characteristics, essence and specific of development of creative personality of the preschoolers; the diagnosis of this quality in children; drafting of the integrated characteristics of creative aptitudes and abilities of the preschoolers; design of educational, creative, studentcentered living environment to children.

The first series of diagnostic procedures concerned the indicators of the motivational and valuable criterion. In order to diagnose the indicators of motivational and valuable criteria of future specialists of preschool education to creative self-realization readiness, the diagnostic tasks and methods of their implementation were developed.

The indicators of motivational and valuable criterion were: positive attitude toward creative self-realization; interest in the chosen field of study; awareness of the need to creative self-realization by future teachers of preschool education

The second series of diagnostic procedures concerned the indicators of the creative activity criterion. The indicators of this criterion were: the ability to solve pedagogical situations of various directions in the professional activity creatively, the ability to make individual plans of creative self-realization in professional activity, the ability to determine the direction of preschoolers' creative development 
The third series of diagnostic procedures concerned the indicators of the evaluation criterion: capacity for self-assessment of readiness to creative self-realization in professional activity, capacity for assessment of colleagues' readiness to creative self-realization in professional activity.

\section{Research findings}

Within the framework of a certain approach, the levels of readiness of future specialists of preschool education to creative self-realization in professional activity were characterized by a set of certain parameters, which served as certain criteria and indicators. The degree of manifestation of each of the indicators determined the level of readiness of future specialists of preschool education to creative self-realization in professional activity.

The studying of the totality of personal qualities and properties, professional knowledge and skills formed in future preschool teachers, with certain criteria and indicators of readiness of future specialists of preschool education to creative self-realization in professional activity allowed us to characterize the levels of the indicated readiness: primary, reproductive and creative. Let's characterize them.

Creative level. Students have internal positive motivation for creative professional activity and self-realization; have a positive attitude to the creative professional activity of preschool teacher; creatively solve pedagogical situations of various kinds of professional activity; have a sufficient level of knowledge about the creative self-realization, creativity; know how to make long-term plans of individual creative self-realization in professional activity; determine the direction of creative development of preschoolers; they are capable of self-analysis and mutual analysis; they objectively assess their own readiness to creative self-realization in professional activity and their colleagues' readiness to creative self-realization.

Reproductive level. The students don't have a sustained motivation to creative professional activity and self-realization; students solve pedagogical situations of various kinds of professional activity of preschool teacher by analogy; demonstrate a fragmented, non-systemic knowledge about creative self-realization of preschool teacher; creativity does not allow them to make long-term plans of individual creative self-realization in professional activity easily; students are surface-oriented in the areas of creative development of personality of preschoolers; they have difficulties in reflecting on their readiness to creative self-realization and evaluating their colleagues' readiness to creative self-realization.

Primary level. Students reproduce the knowledge mechanically, they are not interested in creative professional activity; they do not realize the significance and importance of creative selfrealization of preschool teacher; they solve pedagogical situations of various kinds of professional activity of preschool teacher mechanically, they are not interested in improving their professional knowledge and skills; they have lack of knowledge about the creative self-realization, creativity; they can't make long-term plans of individual creative self-realization in professional activity; they are not oriented in the directions of creative development of the personality of preschooler; they have a low level of ability to self-assess their readiness to creative self-realization, often they do not adequately assess the readiness of their colleagues to creative self-realization. Table 1 shows the levels of readiness of future specialists of preschool education to creative selfrealization in professional activity according to certain criteria. 
Table 1.

The distribution of the levels of future specialists of preschool education readiness to creative self-realization in professional activity (in \%)

\begin{tabular}{|c|c|c|c|}
\hline \multirow{2}{*}{$\begin{array}{l}\text { Criteria for students' } \\
\text { readiness assessing }\end{array}$} & \multicolumn{3}{|c|}{ The levels of students' readiness } \\
\hline & Creative level & Reproductive level & Experimental group \\
\hline Motivational and valuable & 0 & 21 & 79 \\
\hline Creative activity & 7,6 & 49,5 & 42,9 \\
\hline Evaluation & 3,8 & 39,1 & 57,1 \\
\hline & Control \& & & \\
\hline Motivational and valuable & 0 & 19,6 & 80,4 \\
\hline Creative activity & 6,2 & 42,9 & 50,9 \\
\hline Evaluation & 1,8 & 36,6 & 61,6 \\
\hline
\end{tabular}

According to the results of diagnostics of future specialists of preschool education readiness to creative self-realization in the professional activity revealed that majority of the students in EG (79 \% by the motivational and valuable criterion, $42.9 \%$ by the creative activity criteria, $57.1 \%$ by the evaluation criterion) and $\mathrm{KG}(80,4 \%$ motivational and valuable criterion, $50.9 \%$ by the creative activity criterion and $61,6 \%$ by the evaluation criterion) have the primary level of readiness to creative self-realization in professional activity.

So, according the motivational and valuable criterion, a qualitative evaluation suggests that the students $(79 \% \mathrm{EG}, 80,4 \% \mathrm{KG}$ - primary level; $21 \% \mathrm{EG}, 19.6 \%$ of $\mathrm{KG}$ - reproductive level; $0 \% \mathrm{EG}$ and $\mathrm{KG}$ - creative level) do not show interest in professional activity; do not see the ways of self-realization in creative activity of preschool teacher and are not internally motivated to be creative.

According the creative activity criterion were dominated the primary $(50.9 \% \mathrm{EG}$ and $61.6 \% \mathrm{KG})$ and reproductive $(49.5 \% \mathrm{EG}$ and $42.9 \% \mathrm{KG})$ levels. The primary level of future preschool teachers to creative self-realization readiness in professional activity according to the creative activity criterion indicates the lack of ability to solve pedagogical situations of various directions creatively, plan self-educational activity, make individual plans of creative selfrealization in professional activity; the majority of students at the primary level determine the directions of creative development of the personality of preschooler.

According to the results of the tasks performed according to the evaluation criteria, the primary $(57.1 \% \mathrm{EG}$ and $61.6 \% \mathrm{KG})$ and reproductive $(39.1 \% \mathrm{EG}, 36.6 \% \mathrm{KG})$ levels were dominated. The primary level of future preschool teachers' readiness to creative self-realization in professional activity according to the evaluation criteria indicates a low level of students ' communicative and analytical skills.

Thus, it was found that for the majority of students of EG (79\% by the motivational and valuable criterion, $42.9 \%$ by the creative-activity criterion, $57.1 \%$ by the evaluation criterion) and $\mathrm{KG}(80.4 \%$ by the motivational and valuable criterion, $50.9 \%$ by the creative-activity criterion, and $61.6 \%$ by the evaluation criterion) have the primary level of readiness to creative self-realization in professional activity.

In the process of conducting an experimental study, it was found that, in general, future preschool teachers have primary and reproductive levels of readiness to creative self-realization in professional activity according to the motivational and valuable criterion. The creative level was not recorded at all. 
Experimental data shows the need to improve the process of future preschool teachers' special training.

\section{Conclusion}

Criteria (motivational and valuable, creative-activity, evaluation) and indicators of future preschool teachers' readiness to creative self-realization in professional activity were defined. Qualitative measurements of the creative, reproductive and primary levels of future preschool teachers' readiness to creative self-realization in professional activity were characterized.

We developed the methodological tool that provided the psychological and pedagogical diagnostics of future preschool teachers' readiness to creative self-realization in professional activity.

The results of the study revealed the main problems of students associated with the fact that most students are neutral about creative self-realization in future professional activity; they have lack the ability to solve pedagogical situations of various directions creatively, plan selfeducational activity, make long-term individual plans of creative self-realization in professional activity; students mainly at the primary level determine the directions of creative development of the personality of preschooler; students at the primary level have communicative and analytical skills.

Further research will be aimed at developing an effective methodology for forming the readiness of future preschool specialists to creative self-realization in professional activity.

\section{References}

Ball, H.O. (1994). Humanistychni zasady pedahohichnoi diialnosti [Humanistic principles of pedagogical activity]. Pedahohika i psykholohiia - Pedagogy and psychology, 2, 8-17.

Bekh, I.D. (2003). Vihovannya osobistosti: u 2 knygakh. Knyga 1: Osobistisno orientovanij pidhid: teoretiko-tekhnologichni zasadi [Education of the person. In 2 books. Book 1: Personally oriented approach: theoretical and technological principles]. Kyiv: Lybid.

Bielienka, H.V. (2011). Formuvannia profesiinoi kompetentnosti suchasnoho vykhovatelia doshkilnoho navchalnoho zakladu: monohr. [Preschool teacher's professional competence formation]. Kyiv: Kyiv. un-t im. B. Hrinchenka.

Biriuk, L.Ya. (2018). Profesiina pidhotovka maibutnikh uchyteliv pochatkovoi osvity: realnyi shans zminyty shkolu, zminity krainu [Professional training of future primary education teachers: a real chance to change the school, change the country]. Bulletin of Taras Shevchenko Luhansk National University, 3.

Bohush, A.M. (2017). Suchasnyi pidkhid do modernizatsii navchalno-vykhovnoho protsesu vyshchoi shkoly [Modern Approach to the Issue of Higher Education Modernization]. Nauka i osvita - Science and Education, 5, 14-18.

Bryzgalova, S.I. (2004). Formyrovanye v vuze hotovnosty uchytelia k pedahohycheskomu yssledovanyiu: teoryia y praktyka [Formation and development of professional and moral culture of the future teacher: dis]. Kaliningrad.

Voitiuk, D. K. (2004). Vliyanie refleksii na formirovanie psihologicheskoy gotovnosti lichnosti $\mathrm{k}$ professionalnoy deyatelnosti [Influence of reflection on the formation of psychological readiness of an individual for professional activity: dis. cand. pedag. scien.]. Novosibirsk, 2004.

Holota, N.M. (2000). Formuvannia khudozhnikh i konstruktyvnykh umin u maibutnikh vykhovateliv doshkilnykh zakladiv: Avtoref. dys... kand. ped. nauk : [Formation of 
artistic and constructive abilities of future educators of preschool establishments]: the dissertation author's abstract. Kyiv.

Davkush, N. (2012). Formuvannia prohnostychnoi kompetentnosti maibutnikh vykhovateliv doshkilnykh zakladiv $\mathrm{v}$ umovakh VNZ [Formation of predictive competence of future preschool teachers in HEI]. Pedagogy and psychology of professional education, 1.

Demydenko, V. (2004). Samorealizatsiia: sutnist, stanovlennia, rozvytok. Pedahohika i psykholohiia [Self-realization: essence, formation, development. Pedagogy and psychology]. Pedahohika i psykholohiia, 2(43), 31-36.

Dubaseniuk, O. (2017). Osoblyvosti struktury pedahohichnoi diialnosti vchytelia v konteksti suchasnykh naukovykh pidkhodiv [Features of the structure of teacher's pedagogical activity in the context of modern scientific approaches]. Bulletin of Taras Shevchenko national University of Kiev. Pedagogy, 1.

Durai-Novakova, K.M. (1983). Formyrovanye professyonalnoi hotovnosty studentov k pedahohycheskoi deiatelnosty [Formation of professional readiness of students for pedagogical activity: autoref. dis] Moscow: Izd-vo MG.

Diachenko, M.I., Kandybovich, L.A. (1998). Kratkij psihologicheskij slovar': Lichnost, obrazovanie, samoobrazovanie, professiya [Brief psychological dictionary: Personality, education, self-education, profession]. Minsk: Hehlton.

Zhyhailo, N.I. (2019). Psykholohiia osobystisnoho ta dukhovnoho zrostannia lidera [Psychology of personal and spiritual growth of a leader]. Psychologiczny journal, 1.

Zalizniak, A.M. (2009). Pidhotovka maibutnikh vykhovateliv do roboty $\mathrm{z}$ batkamy z moralnoho vykhovannia ditei starshoho doshkilnoho viku : avtoref. dys. kand. ped. nauk [Training of future teachers to work with parents on moral education of children of senior preschool age: autoref. dis.]. Uman.

Kan-Kalyk, V.A. (1990). Pedagogicheskoye tvorchestvo. [Pedagogical creativity]. Moscow: Pedagogika.

Kapska, A. (1997). Pedahohika zhyvoho slova [Pedagogy of the word]. Kyiv.

Kovalevska, N.V. (2007). Profesiina pidhotovka studentiv fakultetiv doshkilnoi pedahohiky do roboty u simiakh [Professional training of students of the faculties of preschool pedagogy to work in families]. Dissertation for the degree of candidate of pedagogical Sciences in the specialty Kyiv.

Kovalenko, Yu.O. (2006) Teoretychni i metodychni zasady pidhotovky fakhivtsiv fizychnoho vykhovannia ditei doshkilnoho viku [Theoretical and methodological bases of training specialists in physical education of preschool children]. Kharkiv.

Kondrashova, L. (1987). Moralno-psykholohichna hotovnist studenta do vchytelskoi diialnosti [Moral and psychological readiness of the student for teaching activities]. Kyiv.

Korostyliova, L. (1996). Samorealizatsiya lichnosti kak psikhologicheskaya problema [Selfrealization of a person as a psychological problem]. St-Petersburg.

Kuzmina, N. (1990) Professyonalyzm lychnosty prepodavatelia y mastera proyzvodstvennoho obuchenyia [Professionalism of the teacher and Master of Industrial Training.]. Moscow

Levitov, N. (1964). O psihicheskih sostoyaniyah cheloveka [About mental states of a person]. Moscow.

Leontiev, O. (1983). Deyatelnost. Soznanie. Lichnost. Izbrannyie psihologicheskie proizvedeniya: v 2-h t. [Activity. Consciousness. Personality. Selected psychological works: in 2 vols.] Moscow.

Lystopad, O. A. (2015). Eksperymentalne doslidzhennia formuvannia profesiino-tvorchoho potentsialu maibutnikh vykhovateliv doshkilnykh navchalnykh zakladiv [Experimental study of the formation of professional and creative potential of future teachers of preschool educational institutions]. Science and education, 9.

Lutsan, N.I. (2019). Problemy ta perspektyvy fakhovoi pidhotovky suchasnoho pedahoha v umovakh rozbudovy Novoi ukrainskoi shkoly: zbirnyk materialiv Vseukrainskoi naukovo-praktychnoi internet-konferentsii [Problems and prospects of professional 
training of a modern teacher in the conditions of development of a New Ukrainian school: collection of materials of the all-Ukrainian scientific and practical Internet conference]. Ivano-Frankivsk.

Liubyva, V.V. (2018). Formuvannia hotovnosti maibutnikh fakhivtsiv doshkilnoi osvity do tvorchoi samorealizatsii u profesiinii diialnosti: avtoref. dys. ... kand. ped. nauk [Formation of readiness of future specialists of preschool education to creative selfrealization in professional activity: autoref. dis.]. Hlukhiv.

Makridina, L.O. (1996). Formuvannia u studentiv pedahohichnykh uchylyshch tvorchoho stavlennia do profesiinoi diialnosti: avtoref. dys. na zdobuttia nauk, stupenia kand. ped. nauk [Formation of creative attitude to professional activity among students of pedagogical schools: autoref. dis. for the degree of candidate of science]. Kyiv.

Mardarova, I. K. (2012) Pidhotovka maibutnikh vykhovateliv do vykorystannia kompiuternykh tekhnolohii v orhanizatsii piznavalnoi diialnosti starshykh doshkilnykiv [Preparing future preschool teachers to computer technologies using in the organization of cognitive activities of senior preschoolers: autoref. dis. for the degree of candidate of science]. Odessa.

Maksymenko, S.D. (1994). Fakhivtsia potribno modeliuvaty [The specialist needs to be modeled]. Kyiv.

Moliako, V. A. (1995). Psykhologiya detskoy odarennosti [Psychology of child giftedness]. Kyiv.

Mordous, I. (2011). Osobystisno-profesiinyi komponent fakhovoi hotovnosti maibutnoho vchytelia inozemnoi movy v DNZ [Personal and professional component of professional readiness of the future foreign language teacher in the preschool educational institution]. Kyiv.

Naumenko, T.S. (2008). Ekolohichne vykhovannia ditei starshoho doshkilnoho viku zasobamy avtorskoi kazky [Ecological education of children of senior preschool age by means of the author's fairy tale: autoref. dis.]. Kyiv.

Petrenko, S.A. (2005). Model pidhotovky maibutnoho vykhovatelia do formuvannia i osnovnykh rukhovykh umin ta navychok u doshkilnykiv [Model of training of the future preschool teacher for the formation basic motor skills in preschoolers]. Oleksandr Dovzhenko Hlukhiv National Pedagogical University Hlukhiv: Series «Pedagogical Sciences».

Radul, V.V. (2011). Osoblyvosti profesiinoi sotsializatsii osobystosti. [Features of professional socialization of the individual]. Mykolaiv: Scientific Bulletin of the Nikolaev state University Series: Pedagogical Sciences.

Semychenko V. A. (2004) Problemyi motivatsii povedeniya i deyatelnosti cheloveka: modulnyiy kurs psihologii [Problems of motivation of behavior and human activity: a module course in psychology.] Kiev.

Slastionin, V. (1981). Professionalnaya gotovnost uchitelya k vospitatelnoy rabote [Professional readiness of the teacher for educational work. Soviet pedagogy]. Sovetskaya pedagogika, 4.

Timofieieva, H. (2006). Sotsialno-pedagogicheskie usloviya formirovaniya formirovaniya tvorchestva u vospitateley doshkolnyih obrazovatelnyih ucherezhdeniy [Sociopedagogical conditions of creativity formation formation in preschool teachers of preschool educational institutions: autoref. dis. for the degree of candidate of science]. Moscow.

Uznadze, D. (2001). Psihologiya ustanovki [Psychology of installation]. St-Petersburg.

Chepielieva, N.V. (2016). Samoproektuvannia osobystosti u kryzovykh zhyttievykh obstavynakh [Self-projecting personality in crisis life circumstances. Personality in the conditions of crisis challenges of our time]. Kyiv: Materials of the methodological seminar of the APN of Ukraine ed. by academician of the APN of Ukraine S.D. Maksimenko.

Shkvarina, T.M. (2003). Anhliiska mova dlia ditei doshkilnoho viku (prohrama, metodychni rekomendatsii) [English for preschool children (program, guidelines]. Uman.

Shovkoplias, O.M. (2012). Obgruntuvannia pedahohichnykh umov efektyvnoho formuvannia hotovnosti maibutnikh vykhovateliv doshkilnykh navchalnykh zakladiv do profilaktyko- 
koryhuvalnoi roboty $\mathrm{z}$ doshkilnykamy [Justification of pedagogical conditions for effective formation of readiness of future teachers of preschool educational institutions for preventive and corrective work with preschoolers]. Bulletin of Luhansk Taras Shevchenko national University, Pedagogical science, 22(6).

Maslow, A. H. (1954). Motivation and personality. New York: Harper and Row.

Tomas, E. (2019). Workforce Readiness and the Future of Work. New York: Routledge. 